\title{
Life History of Caloglyphus manure, Sancassania (caloglyphus) berlesei and Tyroghagus putrescentiae (Acari:Acaridae) Feeding on Root-Knot Nematodes, Meloidogyne incognita . \\ Doaa A. Abou El Atta;Mariam G. Habashy;Amira E. Mesbah and Alyaa A. Tawfik Plants Protection Res. Institute, Dokki, Agric. Res. Center, Giza, Egypt
}

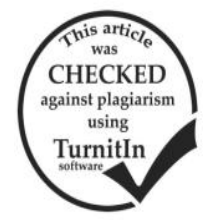

\section{ABSTRACT}

The biology and life table of three acarid mite, Caloglyphus manure Eraky\&Osman, Sancassania (Caloglyphus) berlesei (Michael) and Tyroghagus putrescentiae (Schank) fed on the eggmasses of root-knot nematode Meloidogyn. incognita (Kofoid and White), at $25^{\circ} \mathrm{C} \pm 1$ and R.H $70 \pm 10 \%$. Life cycle durated 13.52, 7.92 and 12.6 days for female and 13.17, 7.31 and 11.29 for male of $C$. manure, S. berlesei and T. putrescentiae, respectively. Female life span averaged 32.72,28.47 and 36.75 days while these of male averaged 19.23, 25.7 and 31.29 days. The mean generation time (T) averaged 19.45, 12.27 and 17.75days,while net reproductive rate $\left(\mathrm{R}_{0}\right)$ values were $83.81,94.53$ and 117.04 time of the aforementioned three mites, respectively. The net rate of natural increase $\left(\mathrm{r}_{\mathrm{m}}\right)$ was $0.227,0.370$ and 0.268 individual / $/$ /day, while the finite rate of increase ( $\mathrm{e}^{\mathrm{rm})}$ averaged $1.255,1.44$ and 1.307 time / $/$ /day of C. manure, S. berlesei and T. putrescentiae, respectively. The results indicate the possibility of using Caloglyphus manure, Sancassania berlesei and Tyroghagus putrescentiae in controlling Meloidogyn. incognita .

\section{INTRODUCTION}

Root-knot nematode,Meloidogyen spp., is economically imprtant agricultural pest with a wide host range Moens et al. 2009. Nematicides can be used effectively for controlling root-knot nematode but public concerns about pesticide residues have encouraged the implementation of the measures such as biological control of these pests El-sherif and Ismail 2009. Acaridae, belonging to Astigmata, is large family of worldwide distribution. About 400 species acarid mites belonging to nearly 90 genera are known in the world and many other to be identified especially in the tropical area Zhang,2003 .

The acarid mites have been proposed as promising biocontrol agents for the management of plant parasitic nematode Sell 1988;Walia and Mathur 1995.The acarid mites, Caloglyphus manure Eraky, Osman has been reported preying on plant parasitic nematode Eraky, and Osman, 2008 .Sancassania sp. was reported to feed on eggs, juveniles and females of Meloidogyne spp. Timms et al. 1981; Sell 1988; Karagoz et al. 2007 .Tyrophagus putrescentiae (Schand) and Hypoaspis calcuttaensis were found to feed juveniles and eggmasses of M. javanica (Walia and Mather 1995). The present work aims to study the different biological aspects of Caloglyphus manure Eraky, Osman, T. putrescentiae and S. berlesei when fed on the egg masses of Meloidogyne incognita at $25^{\circ}$ $\mathrm{C} \pm 1$ in the laboratatory .

\section{MATERIALS AND METHODS}

\section{Root-knot nematode culture :}

A single eggmass used for making a pure culture of the M. incognita was cultured from on coleus plant, then Coleus blumei L. which cultivated in plastic pots $(25 \mathrm{~cm})$ in a greenhouse. After that, (Hussey and Barker, 1973) technique were used to desolved eggmass in $0.5 \%$ sodium hypochlorite then calculating the collected eggs averaged 250 eggs/ eggmass.

Acarid mites culture :

Tullgren funnels used for extracted the three mites $C$. manure, $S$. berlesei and $T$. putrescentiae from chicken manure using, and cultured in the laboratory. Two types of plastic cells containing a floor of plaster of paris and charcoal were used.The first big rearing cells (2.5 cm diameter and $2 \mathrm{~cm}$ depth) were used for mite cultures. The second small ones were $(1 \mathrm{~cm}$ in diameter and $0.8 \mathrm{~cm}$ depth) were used for the biological experiments where a heavy glass cover was used for each cell to prevent mites from escaping The plaster of Paris floor was kept moderately moist . Acaridid cultures kept in the big rearing cells representing three major groups according to kind of mite. All groups were provided daily with eggmasses of root-knot nematode as prey to count food consumpition. the small units used to deposited eggs of the tested mite species singly

Obtained data recognized twice daily for the whole life span . 20 newly hatched larvae were started with each experiment. data was analyzed by one-way analysis (ANOVA) and the means were separated using Duncan's multiple range test (Cohort Software, 2004).

\section{Life table analyses:}

Birch's method (1948) were used for calculated Life table parameters using a BASIC computer program (Abou-Setta,et al.1986) The following population growth parameter were determaind, the mean generation time (T), gross reproductive rate (GRR), the net reproductive increase (R0), the intrinsic rate of increase $(\mathrm{rm})$, the finite rat of increase (erm), and the doubling time (DT). According to Carey (1993). The life tables were prepared from data recorded daily on developmental time (egg to first egg laid), sex ratio, the number of deposited eggs the fraction of eggs reaching maturity and the surviving females. The age class for constructing the life tables was chosen an interval of one day.

\section{RESULTS AND DISCUSSION}

\section{Immature stages:}

Table (1) showed that $S$. berlisie female and male larvae hatched after 3.8 and 3.7 days; while for $T$. putrescntiae 2.45 and 2.2 days and for C.manuri 2.1 and 2.0 days respectively .On the other hand, life cycle averaged 13.52, 12.6 and 7.92 days for female and 13.17, 11.29 and 7.31 days for male to $S$. berlisie, $T$. 
putrescntiae and C.manuri respectively. Generally, male immature had shorter life cycle than females. Similar results were obtained by Osman and Eraky (2008) who reared C.manuri on eggmasses of Meloidogyne spp. and found that life cycle durated 10.4 and 8.1 days for female and male, respectively . Abou El-Atta et al.(2014) mentiond that female and male life cycle of
C.manuri fed on Meloidogyne spp. was 7.92 and 7.82 days respectively, at $25^{\circ} \mathrm{C}$. Hawever, S. berlisie female and male life cycle was 13.6 and 13.8 days when reared on Meloidogyne spp. at $25^{\circ} \mathrm{C}$ Abou El-Atta et al.,(2014) . Whereas, Walia and Mather (1998) indicated that $T$. putrescntiae female life cycle durated 13.12 days when reared on juveniles of M. javanica.

Table 1. Duration (in days) of $S$. berlisie, C.manuri and $T$. putrescntiae developmental stages fed on Meloidogyne incognita and kept at $25 \mathrm{C} \pm 1$ and R.H $70 \pm 10 \%$.

\begin{tabular}{|c|c|c|c|c|c|c|c|c|c|c|}
\hline mite & Sex & Egg & larva & $\mathbf{Q}$ & protonymph & $\mathbf{Q}$ & Tirtoymph & $\mathbf{Q}$ & Immature & Life cycle \\
\hline Sancassania & 우 & $3.8 \mathrm{a} \pm 0.917$ & $2.95 \mathrm{a} \pm 0.184$ & $1.05 \mathrm{a} \pm 0.05$ & $1.45 b \pm 0.15$ & $0.97 \mathrm{a} \pm 0.025$ & $2.35 \mathrm{a} \pm 0.15$ & $0.95 \mathrm{a} \pm 0.03$ & $9.72 \mathrm{a} \pm 0.282$ & $13.52 \mathrm{a} \pm 0.241$ \\
\hline berlesie & $\hat{\sigma}$ & $3.7 \mathrm{a} \pm 0.068$ & $2.85 \mathrm{a} \pm 0.166$ & $1.03 \mathrm{a} \pm 0.105$ & $1.35 \mathrm{~b} \pm 0.109$ & $0.9 \mathrm{a} \pm 0.057$ & $2.15 a \pm 0.15$ & $0.92 \mathrm{a} \pm 0.068$ & $89.47 a \pm 0.075$ & $13.17 \mathrm{a}$ \\
\hline Caloglyphus & q & $2.1 \mathrm{c} \pm 0.06$ & $0.95 c \pm 0.03$ & $0.87 \mathrm{~b} \pm 0.49$ & $1.0 \mathrm{c} \pm 0.062$ & $1.05 \mathrm{a} \pm 0.05$ & $0.95 b \pm 0.034$ & $1.0 \mathrm{a} \pm 0.06$ & $5.82 \mathrm{~b} \pm 0.127$ & $7.92 \mathrm{c} \pm 0.083$ \\
\hline manuri & $\hat{\sigma}$ & $2.0 \mathrm{c} \pm 0.099$ & $0.92 b \pm 0.04$ & $0.75 b \pm 0.057$ & $0.95 c \pm 0.034$ & $0.87 b \pm 0.04$ & $0.9 \mathrm{c} \pm 0.081$ & $0.92 \mathrm{a} \pm 0.075$ & $55.31 \mathrm{~b} \pm 0.104$ & $=0.116$ \\
\hline Tyroghagus & 우 & $2.45 b \pm 0.114$ & $2.55 b \pm 0.114$ & $1.07 \mathrm{a} \pm 0.054$ & $2.2 \mathrm{a} \pm 0.17$ & $1.07 \mathrm{a} \pm 0.04$ & $2.15 \mathrm{a} \pm 0.131$ & $1.1 \mathrm{a} \pm 0.06$ & $10.15 \mathrm{a} \pm 0.232$ & $12.6 b \pm 0.222$ \\
\hline putrescentiae & 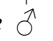 & $2.2 \mathrm{~b} \pm 0.114$ & $2.4 \mathrm{a} \pm 0.112$ & $1.0 \mathrm{a} \pm 0.071$ & $1.85 \mathrm{a} \pm 0.081$ & $0.99 \mathrm{ab} \pm 0.033$ & $31.75 b \pm 0.142$ & $1.1 \mathrm{a} \pm 0.071$ & $9.09 a \pm 0.225$ & $11.29 b \pm 0.31$ \\
\hline \multirow{2}{*}{ LSD } & q & 0.264 & 0.359 & 0.145 & 0.390 & 0.113 & 0.33 & 0.162 & 0.632 & 0.554 \\
\hline & $\hat{\sigma}$ & 0.271 & 0.335 & 0.228 & 0.230 & 0.135 & 0.364 & 0.203 & 0.656 & 0.706 \\
\hline
\end{tabular}

\section{Adults stage :}

Table(2) showed that the females lived for longer time than males. Females began to deposit eggs after $1.35,1.3$ and 0.4 days and laied an average of 227.75, 190.75 and 168.8 eggs for T. putrescntiae, S. berlisie and C.manuri, respectively (Tables 2,5) . The adult female lived for $24.15,20.55$ and 19.2 days and life span averaged $36.75,28.47$ and 32.72 days for females and 20.0, 18.4 and 6.05 for male of T. putrescntiae, C.manuri and S. berlisie, respectively. Eraky, (1987) reported that C.berlesi deposited an average of 755.7 eggs Walia and Mather (1998) found that $T$. putrescntiae female liad an average of 171.40 eggs when reared on juveniles of $M$. javanica Morcover,
.Chmielewski (2000) found that mean deposited eggs per female of C.berlesi was 221.7 when reared on beebread. He also found (2003), that its fecundity average 237.4 eggs when reared on buckwheat sprouts . Also in Eraky and Osman (2008) reported that C.manuri female of laid 601.4, 535.0 and159.1 eggs and lived for 15.7, 11.6 and 17.8 days when reared on yeast, dry cheese and root knot nematode respectively.

Concecerinig prey consumpation, data in table (3) clearly indicated that larvae of the three mites $S$. berlisie, C.manuri and T. putrescntiae fed on an average of 1.42, 0.55 and 1.3 eggmasses for female and $1.42,0.5$ and 1.35 for male respectively.

Table 2. Duration (in days) of $S$. berlisie, C.manuri and $T$. putrescntiae adult stages fed on Meloidogyne incognita and kept at $25 \mathrm{C} \pm 1$ and R.H $70 \pm 10 \%$.

\begin{tabular}{|c|c|c|c|c|c|c|}
\hline mite & Sex & Preovi. & Ovip. & Postovi. & Longevity & Lifespan \\
\hline Sancassania & $q$ & $1.3 \mathrm{a} \pm 0.127$ & $12.95 \mathrm{~b} \pm 1019$ & $4.95 \mathrm{a} \pm 0.366$ & $19.2 \mathrm{a} \pm 1.424$ & $32.72 \mathrm{ab} \pm 1.467$ \\
\hline berlesie & $\hat{0}$ & --------- & -------- & ------- & $6.05 b \pm 0.734$ & $19.23 c \pm 0.769$ \\
\hline Caloglyphus & $q$ & $1.35 \mathrm{a} \pm 0.109$ & $11.56 \mathrm{~b} \pm 1.32$ & $7.55 \mathrm{a} \pm 1.296$ & $20.55 \mathrm{a} \pm 2.08$ & $28.47 \mathrm{~b} \pm 2.084$ \\
\hline manuri & $\hat{\sigma}$ & ------- & -------- & -------- & $18.4 \mathrm{a} \pm 2.193$ & $25.7 b \pm 2.155$ \\
\hline Tyroghagus & $q$ & $0.4 \mathrm{~b} 0.112$ & $17.8 \mathrm{a} \pm 2.124$ & $6.05 \mathrm{a} \pm 1.195$ & $24.15 \mathrm{a} \pm 2.47$ & $36.75 a \pm 2.396$ \\
\hline putrescentiae & $\hat{\sigma}$ & -------- & --------- & -------- & $20 \mathrm{a} \pm 2.148$ & $31.29 \mathrm{a} \pm 2.029$ \\
\hline \multirow{2}{*}{ LSD } & q & 0.330 & 4.539 & 2.944 & 5.782 & 5.720 \\
\hline & $\hat{0}$ & --------- & ------ & -------- & 5.10 & 5.073 \\
\hline
\end{tabular}

Table 3. Number of consumed Meloidogyne incognita egg masses by immature development and adult stage of S. berlisie, C.manuri and T. putrescntiae and kept at $25 \mathrm{C} \pm 1$ and R.H $70 \pm 10 \%$.

\begin{tabular}{|c|c|c|c|c|c|}
\hline mite & Sex & Larva & protonymph & Tirtoymph & Immature \\
\hline Sancassania & $q$ & $1.42 \mathrm{a} \pm 0.090$ & $0.8 \mathrm{a} \pm 0.084$ & $1.22 \mathrm{a} \pm 0.067$ & $3.45 \mathrm{a} \pm 0.13$ \\
\hline berlesie & $\hat{0}$ & $1.42 \mathrm{a} \pm 0.083$ & $0.7 \mathrm{a} \pm 0.056$ & $1.07 \mathrm{a} \pm 0.075$ & $3.2 \mathrm{a} \pm 0.122$ \\
\hline Caloglyphus & q & $0.55 b \pm 0.022$ & $0.6 \mathrm{~b} \pm 0.033$ & $0.67 \mathrm{~b} \pm 0.048$ & $1.82 \mathrm{~b} \pm 0.092$ \\
\hline manuri & $\hat{\sigma}$ & $0.5 b \pm 0.02$ & $0.55 \mathrm{~b} \pm 0.042$ & $0.65 \mathrm{~b} \pm 0.052$ & $1.7 \mathrm{~b} \pm 0.073$ \\
\hline Tyroghagus & q & $1.3 \mathrm{a} \pm 0.91$ & $0.75 \mathrm{ab} \pm 0.076$ & $1.12 \mathrm{a} \pm 0.016$ & $3.17 \mathrm{a} \pm 0.150$ \\
\hline putrescentiae & $\hat{\sigma}$ & $1.35 \mathrm{a} \pm 0.089$ & $0.7 \mathrm{a} \pm 0.05$ & $1.1 \mathrm{a} \pm 0.087$ & $3.15 \mathrm{a} \pm 0.123$ \\
\hline \multirow{2}{*}{ LSD } & 우 & 0.214 & 0.196 & 0.169 & 0.359 \\
\hline & $\hat{\sigma}$ & 0.204 & 0.148 & 0.207 & 0.308 \\
\hline
\end{tabular}

The first nymphal stage where devoured an average of $0.8,0.6$ and 0.75 egg masses for female and $0.7,0.55$ and 0.7 eggmasses for male these values were $1.22,0.67$ and 1.12 for the predator tritonymph female and 1.07, 0.65 and 1.1 for male of $S$. berlisie, C.manuri and $T$. putrescntiae, respectively (table 4 ). Immature stages consumed daily an average of $3.45,1.82$ and 3.17 eggmasses for female and 3.2, 1.7 and 3.15 egg masses for male of $S$. berlisie, C.manuri and T. putrescntiae respectively. During oviposition period the previous data showed no significant difference between $S$. berlisie and $T$. putrescntiae for the predator female 
feeding capacity . Adults consumed 33.9, 57.12 and 45.75 eggmasses of $M$. incognita while male consumed $20.05,16.85$ and 18.85 eggmasses for the three mites $S$. berlisie, C.manuri and T. putrescntiae respectively. Walia and Mathur (1995)reported that the two nematophagous mites, T. putrescntiae and Hypoaspis calcuttaensis, were voracious feeders of nematodes consuming as many as 726 and 811 juveniles of $M$. javanica (Treub), respectively.

\section{Life table parameters:}

The calculated life table parameters have been taken into consideration where: the mean generation time $(\mathrm{T})$, the net reproductive increase (R0), doubling time (DT), the intrinsic rate of increase (rm) and the finite rat of increase (erm)., gross reproductive rate (GRR) .

Concerning life table parameters of $S$. berlisie, C.manuri and $T$. putrescntiae table 5, showed that the mean generation time (T) was significantly affecting of kind of predator $(\mathrm{T})$ values averaged 19.45, 12.27 and 17.75 days of $S$. berlisie, C.manuri and T. putrescntiae respectively. The population of $S$. berlisie, C.manuri and $T$. putrescntiae had the capacity to double every $3.05,1.68$ and 2.58 dayes. Also the net reproductive rat (R0) was significantly affected by kind of mite as (R0) values averaged 83.81, 94.53 and 117.04 at the three mites $S$. berlisie, C.manuri and $T$. putrescntiae respectively. However, the inteinsic rat of natural increase ( $\mathrm{rm})$ is a key demographic parameter useful for predicting the population growth potential of an animal under given environmental conditions (Birch 1948), because ( $\mathrm{rm})$ reflects an overall effect on the development, reproduction and survival. Table 5 showed that (rm) values $0.227,0.370$ and 0.268 individuals/female/day all of three mites $S$. berlisie, C.manuri and $T$. putrescntiae respectively .The finite rate of increase 1.25, 1.44 and 1.20 of $S$. berlisie, C.manuri and T. putrescntiae respectively. Eraky (1995) found that the reproductive rat (R0)and intrinsic rate of increase (rm) were 80.24 and 0.09 whereas, the mean generation time (T) and doubling time (DT)were 49.29 and 7.70 when $T$. putrescntiae (schrank) reared on the bird- cherry aphid Rhopalosiphum padi L. at $18{ }^{\circ} \mathrm{C}$; while , Al-Rehiayani and Fouly (2006) showed that M.javanica eggs was the most suitable food and supported the highest net reproductive rat (R0) to two acarid mites Mycetoglyphus qassimi Pakyari and Magghsoudlo (2011) showed that the intrinsic rate of increase (rm) and the reproductive rat (R0) for $T$. putrescntiae when reared on phytonematode, Ditylenchus destrutor Thome at $25{ }^{\circ} \mathrm{C}$ were 0.16 and 22.28 , respectively .

Table 4. Number of consumed Meloidogyne incognita egg masses by adult stage of $S$. berlisie, $C$.manuri and $T$. putrescntia and kept at $25 \mathrm{C} \pm 1$ and $\mathrm{R} . \mathrm{H} 70 \pm 10 \%$.

\begin{tabular}{|c|c|c|c|c|c|c|}
\hline mite & Sex & Preovi. & Ovip. & Postovi. & Longevity & Lifespan \\
\hline Sancassania & q & $1.3 \mathrm{a} \pm 0.12$ & $24.3 b \pm 2.0$ & $4.85 b \pm 0.35$ & $30.45 \mathrm{c} \pm 2.21$ & $33.9 \mathrm{c} \pm 2.21$ \\
\hline berlesie & $\hat{0}$ & ------- & ------- & ------- & $16.85 \mathrm{a} \pm 1.28$ & $20.05 \mathrm{a} \pm 1.28$ \\
\hline Caloglyphus & q & $1.5 \mathrm{a} \pm 0.11$ & $35.65 \mathrm{a} \pm 3.9$ & $18.15 \mathrm{a} \pm 1.76$ & $55.3 \mathrm{a} \pm 4.56$ & $57.12 \mathrm{a} \pm 4.54$ \\
\hline manuri & $\hat{0}$ & ---------- & --------- & --------- & $15.15 \mathrm{a} \pm 2.035$ & $16.85 \mathrm{a} \pm 2.02$ \\
\hline Tyroghagus & $q$ & $0.87 \mathrm{~b} \pm 0.049$ & $25.35 \mathrm{~b} \pm 2.01$ & $16.53 \pm 1.51$ & $42.57 \mathrm{~b} \pm 3.10$ & $45.75 b \pm 3.12$ \\
\hline putrescentiae & $\hat{\sigma}$ & ----------- & -------- & --------- & $15.6 \mathrm{a} \pm 1.32$ & $18.85 \pm 1.33$ \\
\hline \multirow{2}{*}{ LSD } & 우 & 0.292 & 8.008 & 3.85 & 9.721 & 9.711 \\
\hline & $\sigma^{1}$ & ---------- & --------- & --------- & 4.490 & 4.481 \\
\hline
\end{tabular}

Table 5. life table parameters of $S$. berlisie, C.manuri and $T$. putrescntiae when fed on Meloidogyne incognita and kept at $25 \mathrm{C} \pm 1$ and R.H $70 \pm 10 \%$.

\begin{tabular}{lccccc}
\hline mite & MeanTotal Fecundity & R0 & T & rm & erm \\
Sancassania & $190.75 \pm 17.90$ & 83.81 & 19.45 & 0.227 & 1.255 \\
berlesie & $168.8 \pm 16.72$ & 94.53 & 12.27 & 0.370 & 1.44 \\
Caloglyphus manuri & $227.75 \pm 16.03$ & 117.04 & 17.751 & 0.268 & 1.307 \\
$\begin{array}{l}\text { Tyroghagus } \\
\text { putrescentiae }\end{array}$ & & & & 2.586 \\
\hline
\end{tabular}

\section{REFERENCES}

Abou-Setta M. M., Sorrell,R. W. and Childers C. C. (1986). Life 48 :a BASIC computer program to calculate life table parameters for an insect or mite species. Fla. Entomol. 69 (4): 690-697.

Abou El- Atta, D. A., Genena, M. A. M. and Osman, M. A. (2014). Temperature influence on development and life table parameters of acarid mite, Caloglyphus manuri Eraky \& Osman reared on root knot nematode, Meloidogyne sp. Acarines, 8(1):3-7.
Al-Rehiayani, S. M. and Fouly, A. H. (2006). Mycetoglyphus qassimi and Tyrophgus putrescentiae, two acarid mites recovered from palm fields, feeding on root-knot nematode Meloidogyne javanica in Al-Qassim area, Saudi Arabia. J. King Abdulaziz Univ. Meterol. Environ Arid Land Agric. Sci., 17 : 3-16.

Birch, L. C. (1948). The intrinsic rate natural increase of an insect population J. Anim. Ecol., 17:15-26 .

Carey, J. R. (1993) . Applied demography for biologists with special emphasis on insects. New York : Oxford University Press . 
Chmielewski W. (2000). Proba hodowli rozkruszka Caloglyphus barlesei (Michael) na pierzdze pszczelej. Materialy XVI Naukowej Konferencji "Warroza pszczol I gospodarka pasieczna" Olsztynkortowo : 8-10 .

Chmielewski W. (2003). Effect of buckwheat sprout intake on population increase in Caloglyphus berlesei (Michael)(Acari:Acaridae).Fagopyrum 18:85-88 .

Cohort Software (2004). CoStat, a statistical program (Internet). Monterey (CA).Available from www.cohort.com.

El-Sherif AG, Ismail AF(2009).Integrated management of Meloidogyne incognita infecting soybean by certain organic amendments Bacillus thuringiensis, Trichoderma harzianum and oxamyi with reference to NPK and total chlorophyll status, Plant Pathol 8:159-164 .

Eraky, S. A (1987) . observation on the biology of two species of acarid mites . Folia ent. Hung., 48:2127 .

Eraky, S. A and Osman, M. A. (2008). Some biological aspects and life table parameters of Caloglyphus manuri Eraky \& Osman (Acaridida -Acaridae) fed on different kinds of food. Acarines 2:45-48.

Hussey,R. S. and Barker, K. R. (1973) . A comparison of collecting inoculate of Meloidogyne spp. including a new technique Plant Disease Reporter, 57:1025-1028 .

Karagoz M, Gulcu B, Cakmak I, Kaya HK, Hazir S(2007).Predation of entomopathoginic nematodes by Sancassania sp. (Acari:Acaridae). Exp Appl Acarol 43:85-95 .
Korayem, A. M.;Wahab, A. and Mohamed, M. M.(2007). Management of the root-knot nematode, Meloidogyne incognita on sunflower by a formulated soil amendment.Al-Azhar Journal of Agricalture Research, 3:263-268 .

Moens M. Perry RN. Starr JL(2009). Meloidogyne species a diverse group of novel and important plant parasitic In:Perry RN. Starr JL(eds)Rootknot nematodes . CABI Publishing. Wallingford, pp1-17.

Sell, P(1988). Caloglyphus sp. (Acari:Acaridae) an effective nematophagous mites on Root-knot nematodes Meloidogyne spp. Nematologica, 34:246-248.

Timms S, Ferro DN, EmbersonRM (1981). General biology and nomenclature of Sancassania berlesei (Michael). Acarologia 22:385-390 .

Walia, K.K., and Mathur, S. (1998). Reproductive behavior of two nematophagous mites, nematodes and alternate diet. Annals of Plant Protection Sciences. 6 (2): 178-181.

Walia, K.K., and Mathur,S. (1995). Predatory behavior of tow nematophagous mites, Tyrophgus putrescentiae and Hypoaspis calcuttaensis, on root-knot nematode, Meloidogyne javanica. Nemato. Mediter. 23 (2): 255-261.

Zhang, Z. Q. (2003). Mites of greenhouse. identification biological and control . CABI Publishing. 244 pp.

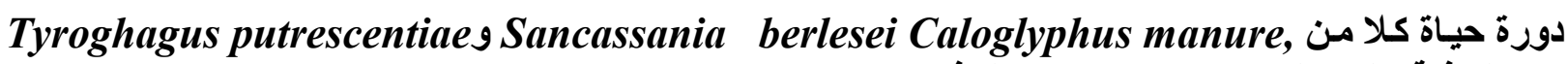

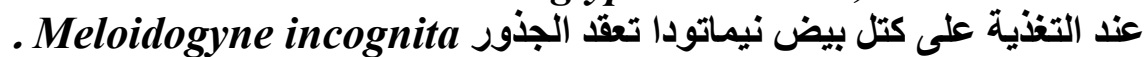

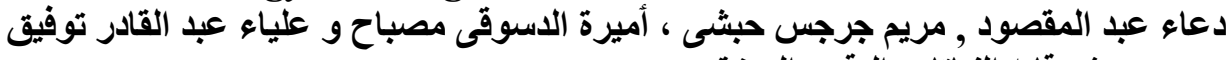

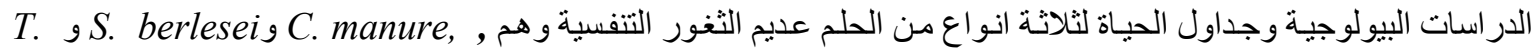
عitrescentiae عند التغذية على كنل بيض نيماتودا تعقد الجذور

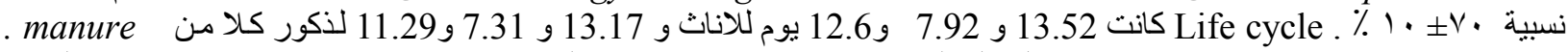
Tلى T. putrescentiae و S. berlesei C

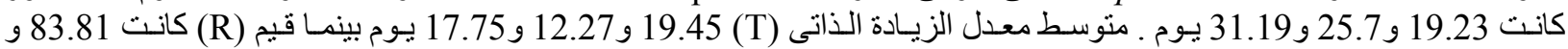

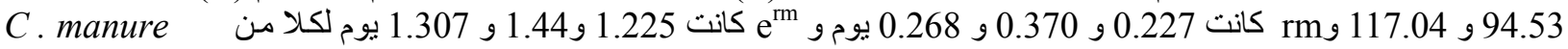
و

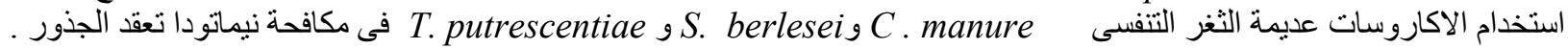

